\title{
Etno mapeamento, georreferenciamento e diagnóstico rural participativo em um território indígena brasileiro
}

\author{
Ethno mapping, georeferencing and participatory rural diagnosis in a Brazilian \\ indigenous territory \\ Mauro Braga Costa Pereira ${ }^{32}$ \\ Érica Dumont Pena ${ }^{33}$ \\ Marivaldo Aparecido de Carvalho ${ }^{34}$ \\ Rosana Passos Cambraia ${ }^{35}$
}

Artigo recebido em para publicação em ago/2013 e aceito para publicação em mar/2014

\section{RESUMO}

O objetivo deste artigo é discutir as possibilidades do trabalho com etno mapas, ferramenta do Diagnóstico Rural Participativo (DRP), em uma comunidade rural indígena no Sudeste Brasileiro. Trata-se de um trabalho, no qual apresentaremos informações georeferenciadas associadas a um diagnóstico, composto por etno mapas temáticos e informações qualitativas da Aldeia Imbiruçu, onde residem os Pataxó, localizada em Carmesia, Minas Gerais, Brasil. A construção dos etno mapas foi realizada de forma dialógica, em conjunto com os indígenas da comunidade e, deste modo geraram reflexões sobre o território. Destacou-se, por parte dos participantes, fatores de vulnerabilidade, especialmente relacionados à saúde ambiental e à segurança alimentar.Também foram evidenciadas áreas de coletas, de plantios de milho e feijão, árvores frutíferas, escola, lago, mata, além das casas. O estudo demonstrou, a nosso ver, a viabilidade da construção de etno mapas no planejamento sustentável realizado pelos próprios indígenas.

Palavras-chave: Diagnóstico participativo. Etnomapas. Povos indígenas. Povo Pataxó. Sistema de informação geográfica.

\section{ABSTRACT}

The aim of this article is to discuss the possibilities to work with ethno maps, a tool of Participatory Rural Diagnosis (PRD), in an indigenous rural community in the Brazilian Southeast. It is a text, in with we will present georeferenced information associated with a diagnosis composed by thematic ethno maps and qualitative information from Imbiruçu, the Pataxó village situated in Carmesia, Minas Gerais, Brazil. The construction of etno maps was in a dialogical way, with the most part of the indigenous who lives there, and in this way, gendered reflections about the territory. The participants recognize vulnerability factors, specially related with the environmental health and the food security. They also evidenced in the maps, the collective areas, agricultural areas for corn and beans, fruit trees, school, lake, forest, besides the houses. The study, for us, evidenced the viability to use the tool in the sustainable planning by the own indigenous.

Keywords: Participative diagnostic. Ethno maps. Indigenous. Pataxó ethnie Geographical information system.

\footnotetext{
32 Graduação em Engenharia Florestal pela Universidade Federal dos Vales do Jequitinhonha e Mucuri (UFVJM). Técnico do Instituto Chico Mendes de Conservação da Biodiversidade (ICMBio). E-mail: mauromoc@yahoo.com.br

33 Graduação em Enfermagem pela Universidade Federal dos Vales do Jequitinhonha e Mucuri (UFVJM) e mestrado em educação no Programa de Pós-Graduação em Educação pela Universidade Federal de Minas Gerais (UFMG). Doutoranda na UFMG. E-maol: ericadumont@gmail.com

${ }^{34}$ Graduação em Ciências Sociais pela Universidade Estadual Paulista (UNESP), doutorado e mestrado em antropologia e sociologia no Programa de Pós-Graduação em Sociologia pela UNESP Araraquara. Professor na Universidade Federal dos Vales do Jequitinhonha e Mucuri (UFVJM). E-mail: marivaldo.aparecido@ufvjm.edu.br 35 Graduação em Zootecnia pela Universidade Federal de Viçosa (UFV), doutorado e mestrado em psicobiologia no Programa de Pós-Graduação em Psicologia pela Universidade de São Paulo (USP Ribeirão Preto). Professora na Universidade Federal dos Vales do Jequitinhonha e Mucuri (UFVJM). E-mail: rosa.cambraia@ufvjm.edu.br
} 


\section{INTRODUCTION}

Besides the common idea that the maps are purely representations of reality, and instruments of space orientation, we do know, that they are cultural and historical tools, used also to dominate communities and theirs riches. . In this way, their production methodology generate different representations and is directly associated to its use and their potential (Correia, 2007).

As we sad, historically, the maps were addressed and produced by dominant groups to dispute territories. In this sense, that remains, in general maps are elaborating with political ends of social and territorial conquest and is disrespected the knowledge of local populations on their territories,, as domain form and maintaining power. Harley (1988) and Black (2005) described the first maps from XIX century, built without empowerment and politicization of indigenous people. In the following century, it was describe in a participatory manner, but with the same political objectives and finally in the decade of 1990, they associate these cartographic instruments with technologies of information, and the aim to contribute for the warranty of indigenous territorial rights. That integration was possible by the union of developmental and environmental ideology, expressed by sustainable development, more effective at the end of XX century.

Virgilio and Barros (2007) in turn, detach the importance of factors as demarcation and maintenance of territorial limits in that process, once these people lived in unlimited territories and today are forced to live in restricted territories. The problem is also aggravated with the disputes between units of conservation and indigenous lands. The conduction of national conservationist policies supported by international organisms and based on the argument of global warming and in environmental problems, enters in conflict with the preservation of cultural diversity. In this scenario, world markets, returned for global ecological services, encourage technical models of conservation that exclude human being, and don't solve local conflicts (Lauriola, 2003).

It is a contradiction: data of 1985 from International Union for Conservation of Nature (IUCN), cited by Lauriola (2003), indicated that $70 \%$ of the protected areas of the world and $86 \%$ of Latin America are inhabited. Studies notes that, when properly supported, traditional people can conciliate cultural maintenance with environmental preservation (Schwartzman and Zimmerman, 2005). There are many examples to 
show that indigenous territories are able to develop sustainable projects for alternative generation of income, transforming these environments in efficient mechanisms for nature conservation. This happens due to the direct dependence on the ownership and use of nature by indigenous people, for their physical and cultural survival and social self-determination.

So, the warranty of effectiveness of the territorial right of indigenous and the contribution for sustainability of these people become crucial factors for conservation of the biological and cultural diversities. In that way, are challenges of these people, the alternatives of environmental management, in order to improve the use of their areas and to guarantee the conservation of geographical limits of the territory.

\section{ETHNO MAPS}

As we sad above, and in agreement with Harley (1988), the maps are part of the language endowed with symbolic dimension and social representations, as well as books, linked the ideologies and of political significance. In that sense, they are a class of images and also a discursive form, in which the symbolic dimension is expressed and it makes possible the reproduction, communication and experimentation of certain political views, economical and/or social. When it is representing the environment in an abstract way and under territorial imperatives, can generates social representations, influencing in process for which the power is exercised.

The cartographic instruments adopted in participatory strategies possess a conceptual variety, that Little (2006) unifies calling them of ethno instruments, denomination adopted in the present study. Already in agreement with Herlihy and Knapp (2003), the ethno instruments allow: 1) to document space information about the use and occupation of the earth; 2) delineate conservation plans; 3) map the biodiversity; 4) protect and manage conservation areas and indigenous reservations; 5) delimit and demarcate claimed lands; 6) educate and empower and 7) build consensus and promote the resolution of conflicts over lands and natural resources. 
In this perspective, the union of the physical and symbolic space (territory) in elaboration of visual representations in agreement with perceptions of the involved population, it is characterized by ethno maps ${ }^{36}$.

The ethno maps then, materialize the indigenous knowledge in cartographic bases that historically were linked to westernization processes, counting with the challenge of inter-relating the indigenous and scientific knowledge, backing to dialogue between these people and several institutions. In that sense, the process of participatory construction can subsidizes the resolution of socio-environmental conflicts, support indigenous behaviors for conservation notion and environmental preservation, aids the management of natural resources for these people in their territories and strengthens indigenous identity and autonomy, among others (Correia, 2007).

The indigenous populations reveal the great need of visualization of their territories (Carvalho, 2006). Therefore, it is also extremely important to materialize the information reported orally in elaboration of cartographic documents. With that association of mental maps projected of the Earth or Indigenous Territory (IT) with conventional means is possible the approach of world representations, which favors the integrity front to the vulnerability of these people. Is well-known the scarcity of cartographic documents in IT that hinder this space visualization.

The coverage of maps is enlarged in the union of participatory instruments, with Geographical Information System (GIS), Global Positioning System (GPS) and remote sensing (Herlihy and Knapp, 2003). GIS is applied in data manipulation or information linked to a certain place in space, which can be represented through elements in a map - the digital cartography (Carvalho, 2006). In that sense, associated to information and community perceptions, this tool aids in the planning of integrated territorial management and in autonomy of the community.

Herlihy and Knapp (2003) affirm that participatory mappings promote change in appropriation, in production and in cartography use. Before as tools of territorial and social domination, in the new perspective they can be used as resistance form to domination and control of their actions locally, seeking their sustainability.

${ }^{36}$ According to The Nature Conservation (2006) should have a superposition between the traditional information community and a georeferenced cartographic basis through a participatory process. 


\section{PARTICIPATORY RURAL DIAGNOSIS (PRD)}

To the construction of ethno maps it is fundamental the occurrence of the dialogic process, for which PRD constitutes an interesting tool (Faria, 2000). The PRD, which could also mean "Dialogue, Reflection, Planning", appeared in Chiang Mai University, that is situated in the north of Thailand, in the second half of 1970.

PRD is defined by Chambers (1994) as "growing focuses and methods driven to allow the local population to share, increase and analyze their knowledge about reality, in order to plan actions and to act in this reality". The diagnosis inserts in the conceptions of the participant research, of the popular education, of the participatory planning. In this way, it can be considered an instrument for a culture circle, which was proposed by the educator Paulo Freire (1996). According to the author, in the culture circle, the "consciousness emerges from the lived world, aims at it, problematizes it, and understands it as human project. (...) restored their amplitude, the conscience opens up for practice of freedom".

The dialogue that is instituted in the diagnosis, does not intend to be a teaching method, but a learning and a reflection process, that aim to change understandings among people, as well as intent to exercise freedom and not just thinking in it as a possibility. In the exercise of freeing, the community recognizes and identifies some aspects as space, time, flow and relationships. It also makes possible to plan actions according to the lived reality bringing the perception of the reasons that can turn that situation, a reality (Freire, 1996). Being the theme this reality, can be possible to elaborate action plans properly, made by the collective. In this context of popular education, it was intend with the proposed dialogue (PRD), the valorization of the life experiences of the indigenous community, with diversities and heterogeneity lived by the several social actors, which allows the lifting and the analysis that departs from the collective knowledge.

\section{TERRITORIAL MANAGEMENT}

The understanding of Little (2006), that the territorial management under political control and environmental management of the geographic space, should have the focus in the territory of a social group or political entity, it is useful to think 
about the necessity to associate the political dimension of territorial control of IT to the environmental works for sustainability.

The ethno instruments have a wide use in territorial management, which doesn't mean to provide a finished planning management, but to offer subsidies to indigenous people and institutions managers of projects, as political and technical tools, of mapping and environmental diagnosis (Correia, 2007). Like this, as we said, more than forms to take a more democratic representation of the reality, these instruments are considered as tools of power due to the political force inserted in these. The importance of the instruments, is also given by the aggregation of the information, and in this context, indigenous people in cooperation with institutions and researchers have been developing ethno mappings of their lands, resources, populations, etc.

Smith (2003) complements this discussion suggesting that the maps that are driven by local populations, can contribute to understand the relation between culture and environment, and at the same time, to defend the interests of the oppressed groups against the exploration of the dominant ones. However, know to, that these visual tools cannot fully represent the indigenous perceptions and the knowledge, mainly when it refers to the relationship of indigenous peoples with their natural resources: how they perceive and use them. In this way, Correia (2007) observe that despite the several themes that can covered in this discussions with the populations as the history, the human occupation, the hunting, the fishing, the extraction, the maps doesn't reach all the indigenous perceptions about each them (Correia, 2007).

Still commonly, that the works produced by traditional communities are depreciated by government institutions; although they represent the control of these communities, over their territory. These institutions often elaborate their own maps in a way to promote the control of the resources and of the population, as well as to impose a government ideology of domination (Orlove, 1991).

\section{OBJECTIVES AND BACKGROUND}

The present study aims to present an experience in an indigenous rural community, with a thematic ethno map, dialogued through DRP, and its power to evidence the spaces and the symbolic universes. So, we intended to demonstrate maps and to contemplate the qualitative perspectives of the territory, once, during the 
dialogue, the cultural, social, political and environmental aspects are approached. It is believed that the characterization of the space, the contact and the valorization of local reality could contribute with the identification of the social actors with the environment. This process also favors the problems visualization, as well as, indicates the possibilities to solve them, which contributes to the autonomy of the community, for an integrated territorial management and for the sustainability.

\section{THE COMMUNITY}

The Pataxó's community is located in the municipal district of Carmesia, that is situated in Rio Doce Valley, in the east of Minas Gerais, and in the southeast of Brazil, with an estimated population, in 2006, of 2,249 inhabitants (IBGE, 2007). In Carmésia, they are more than 300 Pataxó indigenous, added to a small contingent of Krenak and Pankararu families, occupying an area of 3,269.71 hectares (Campos, 2000).

The Pataxó are situated in an indigenous territory that was the "Guarani Indigenous Post": a place to former headquarters of anti-guerrilla trainings during the military regime. The "Guarani Indigenous Post" was donated by the State to the National Indigenous Foundation (Funai), in 1974, through the register number 18,148 (Ferros Registry Office, Minas Gerais) and became an indigenous penal colony, where were received the indigenous from all over Brazil who were considered as criminals: especially those who claimed their lands, as the Pataxó people (CEDEFES, 1987).

The Pataxó language is a branch of the Maxakali's family, of Macro-Jê trunk. While they most express in a Portuguese language, living in Minas Gerais, this group is now working with the indigenous teachers and the children, to resume their original language: the Patxohã.

This people are from Barra Velha, south of Bahia, where they, or their families, lived until approximately 1950. At this time, a part of the group migrated to Minas Gerais due to two events: first, when happened the famous 'Fire of 51', characterized by the violent action of the Bahia State police that disarticulated the communities, dispersing the Pataxó People, as form to promoting the occupation in the area of Porto Seguro; the second was the transformation of 23,000 hectares of their territory in a national park - Monte Pascoal National Park, created in 1943, and having its 
border area officially demarcated in 1961, that hurt their territorial rights constitutionally guaranteed (CEDEFES, 2006).

Despite this situation, in the decade of 80 , most part of the indigenous sheltered in Carmesia returned to their lands in Bahia, and remained in Minas Gerais the population who currently inhabits the place. Recognized as IT, the territory is composed today of four communities: Imbiruçu, Guarani, Retirinho and Alto das Poças, being the first of these the community, the one that focus to make the dialogue. The residents of Imbiruçu constitute an extensive family and they are about 100 people. The community is under a recent transformation process and since a couple of years, it has as a leader a new cacique, which is committed with the cultural rescue and with the social control, working hard for it.

They went through adaptations process when they migrated for a cold area, with the relief that is rough and also with the imposition of a strange culture, after several massacres (Angthichay et al., 2002). Today, as we said, they are struggler, trying to organize and restructure the indigenous school, the small rural production, the work with beekeeping, fish farming and handicraft. They are also examples of charisma, courage and also still victims of exploration and violence.

\section{CURRENT SITUATION}

There are current conquests of citizenship among the indigenous, as the new public positions like health agents and indigenous teachers that favors the intercultural exchange by the communities. In 2003, the Pataxó were in an emergency state because of an uncontrolled fire that destroyed $70 \%$ of their natural preservation area. This fact affected directly the reserve of raw material, foods and also influenced their relationships with the nature and the sacred (Pataxó, 2008).

About their activities, stands out the production and the commercialization of handicrafts, main source of family incomes, besides the family farming. About the last one they use to market the surpluses, such as banana, corn, bean and manioc flour, but with little enthusiasm, due to the low price that is achieved at the market. The Pataxó have been investing in the construction of tanks for fish farming and also dedicated to beekeeping (CEDEFES, 2006).

Since the year of 2007, a mining company (MMX, actually Anglos Ferrous), has been investing in the adjacent region, called Cipó Mountain Range that is in a 
central region of Minas Gerais. In this exploration and in the construction of a water pipeline to transport the iron mineral source, was generated attrition with the Pataxó indigenous of Carmesia. In May of 2008, the Brazilians televisions news and the press showed the attempts to block the highway that crosses the indigenous territory. In this situation they were pressing the company to assume the compensation commitment for the environmental imbalance and others dynamics alterations in the IT.

\section{PARTICIPANTS AND STAGES}

For this researcher, five Pataxó members of Imbiruçu community were chosen by the cacique to represent the community. There was also, a time with all the community residents. The present study was developed in three stages. The first one, consisted in a bibliographical revision based in the following keywords: ethno maps, indigenous people, Participatory Rural Diagnosis (PRD) and Geographic Information System (GIS).

In the second stage, the whole community was invited for a hiking, in general with the indigenous representants, in agreement with the availability of the people. In these walks, were registered the coordinates in a GPS equipment, for a georeferencing of the territory. People were instructed about the use of the equipment during the route, manipulating it. For the georeferencing of the Imbiruçu community, were used equipment GPS Garmim $\square$ Trex Legend. After obtained, the data was transferred to the computer, and the base map was set up using the computer application Tracker Maker Pro $\square$.

In the third moment, it was accomplished the PRD. To increase the information and the dialogue mediation, were adopted the tools suggested by Verdejo (2006): the map of the community and matrix of problems prioritization, with some adaptations. After the meeting with the community and the construction of the map with drawings and with the GPS, we gathered with five representants to reflect and to discuss some fundamental information for the space characterization, based in the maps and guided by an interview semi-structured, previously established by the team.

In this process, the use of a common language for the participants, in order to allow free expression the group, was fundamental construct reflection by citizens that 
are actors of the collective actions. Was also important the valorization of interpersonal changes, the dialogue and the understanding of popular knowledge.

Finally, the georeferencing and diagnosis informations were organized to compose a GIS, with the computer application $\operatorname{ArcGis}{ }^{\circledR}$ 9.2. Figures were constructed containing the thematic ethno maps and the qualitative information of diagnosis.

\section{RESULTS AND DISCUSSION}

There were constructed an ethno map and a GSIS with reference in the perceptions of the territorial by the community, dialogued through PRD. Through the PRD a map was created with the whole community, which was later discussed with five indigenous, representants of the community.

For the mediation of the dialogue a semi-structured interview was constructed with the following questions: "What can we observe here?"; "What that place represents?", "This place was always like this? How was this place before?"; "What would you change in this place?" These instruments provided information to the community about their interpretation of their territory, taking into account the socioenvironmental, the economical and the cultural aspects. The georeferenced information was organized in a digital database form (figure 1). Were noticed in the ethno map, aspects as the community history, their important places, their areas for cultivation, peridomestic environment, local vulnerability, demands and future plans. 


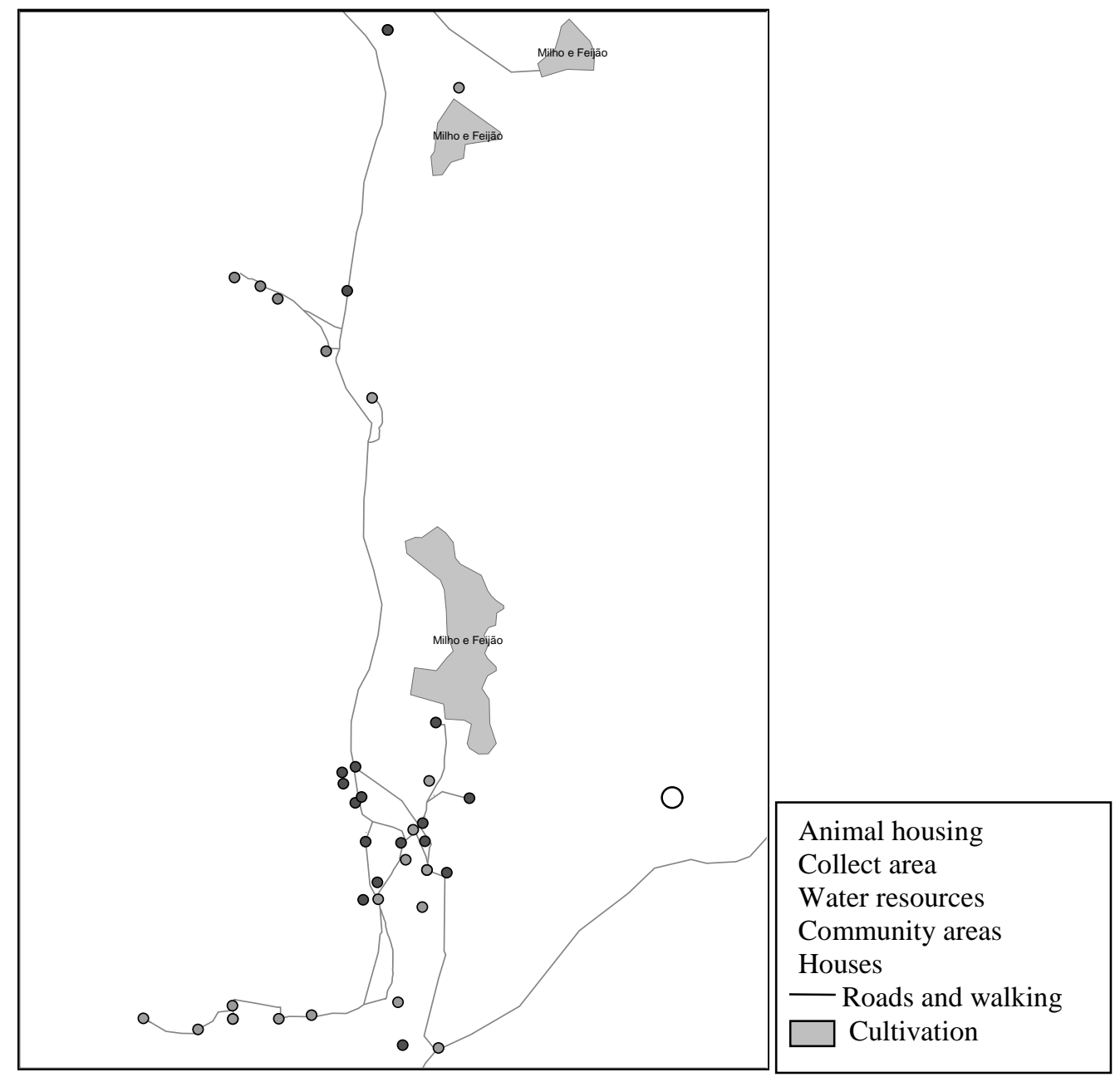

Figure 1 - Ethno maps with the localizations of cultivation, collect areas, water resources, houses, roads and walking ways.

The Imbiruçu community was formed by Ms. Rosa and her late husband Mr. Sebastião, when they came to live in the IT in the decade of 1960. In this decade, they persisted with their migrating habit, they lived at the Guarani's community, following by Retirinho's community and finally stabilized where it is today the Imbiruçu community. At first, all the family use to live at the same house, and today they are twenty families distributed into sixteen homes.

This group of indigenous have drawn and commented the most frequented places by the residents. It was also present on the drawing, the soccer field, very used by the children and the teenagers for the most several games and by the men for soccer games and volleyball.

The conquest of the new work positions as indigenous teachers, health agents, sanitation agents, also redound the alterations in the community's dynamics cultivation. Previously they were used to cultivate and to plant in areas that occupied 
great part of the territory. In this time, each family use to had their corn field (to plant in October), their bean of the water "das águas" (to plant on the water season, in December) and their bean of the time "do tempo" (planted on dry season in March), they also used to cashier and to plant rice. Today, they don't cultivate the bean as before or even the rice and only four families are involved in cultivating and planting the orders ones. However, this work and the crop are still accomplished in the collective efforts involving all of residents, young, adults and seniors.

About the aspects around the homes, in the peridomicile, stands out the necessity of a care regarding the garbage, although this residual is transported twice a week by the municipal truck from Carmesia county service. In these places the children are used to concentrate for games and also there are chickens, dogs, cats and others animals. It is, in the same way, important to detach in this area, a problem faced by residents with their sumps, which the drain capacity is insufficient and also overflow in that area, representing a serious risk for the health.

However it is interesting to notice the presence of Polyvinyl Chloride (PVC) bathrooms implanted by National Health Foundation (Funasa) in the peridomestic area. The bathrooms appear on the children's as a type of home adornment, even this structure doesn't appear to be efficient.

The Imbiruçu community has as socio-environmental problems: some precarious housing, a deficient system of environmental sanitation (water, solid residues and sewage), the alimentary insecurity, environment threatened and is also punished by constants fire and erosion. With the exception of four houses, the other homes of the community are built with bamboo and mud, and without cement. The water supplied to the community was originated from artesian source of the Retirinho community, that is some kilometers far from the Imbiruçu and because of this, they depend on the federal attendance to maintenance the pumps, which is made in an inconstant and in a slow way. In the last months, the residents articulated an alternative system of supply that drives water by gravity, which should contemplate the whole community.

The area of the IT, before the arrival of Pataxó, was a farm land. So, the hills didn't have enough vegetation to cover it, and this problem became worse after the burning. That was also located in a land of mountainous relief and the deforestation 
and the pasturing from the last century, make it a vulnerable place to erosive processes.

The local group receives a little support, or any, for the production of food and the rescue of plants and medicinal herbs. The attempts to implant the fish farming in tanks have limitation in the construction of their own projects, what generating no contextualized alternatives. Before the degradation of water resource, it was possible to fish in the Imbiruçu River, being the fish an important food in the community parties and rituals. In this case, they show that it is important to consider the recovery of the natural environment for generation of perennial resources, traditionally used by the indigenous.

As we said, it was elaborated a matrix of problems prioritization. In that one, we discussed the main problems of the community faced by the order of importance. The school structure was the main problem (with 12 points), the health and artesian water source (4 points) were also pointed, following by burning and lack of support for education (3 points), being still mentioned as priorities the sanitation (sumps) and the necessity to make studies of the water (2 points). There were also discussed the necessity of agricultural machinery and the warranty for differentiated health and education.

From the information generated by the discussions in PRD, we elaborated thematic maps and these maps were associated to the Google Earth ${ }^{\mathrm{TM}}$ view (figure 2). The selected themes were pointed by residents during the diagnosis and suggested opportunely. Then, we prepared the following thematic map: water resources, extraction, animal husbandry, cultivations, homes, trails and communal places. Making a projection for the future, the residents aspirated for the recovery of natural environment and for restructuring the collective spaces, such as the school and the Mõgõga cultural center. 


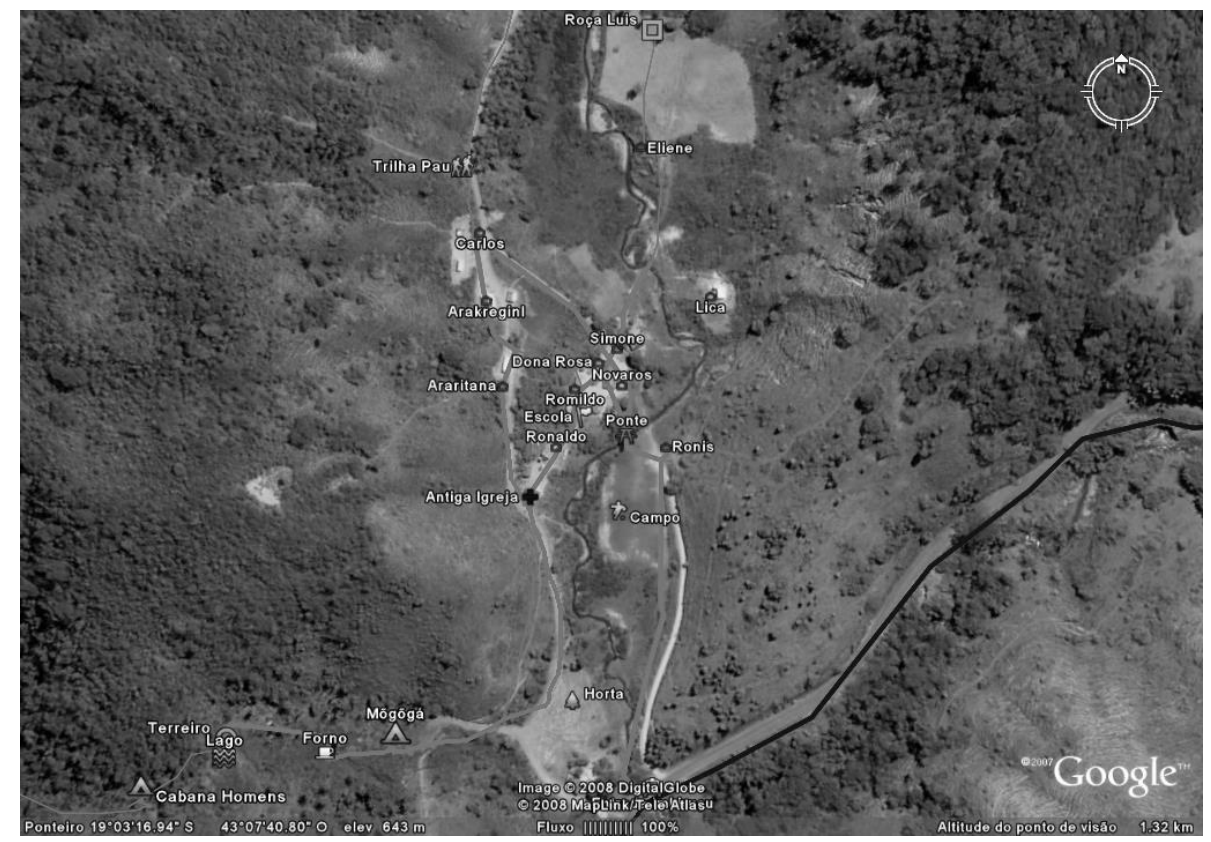

Figure 2 - Image of the central region of Imbiruçu community from Google Earth $^{\mathrm{TM}}$ with superposition of georeferenced information.

According to Melo et al. (2007) about the transformation of information process of traditional communities into a GIS, which serves as base for generation of thematic maps, still demands the existence of a community team with knowledge on geoprocessing and GIS. In this way, institutions and community organizations can reproduce this methodological process, been necessary a continuous training process.

We notice that it was possible the construction of a geographic information system, composed by thematic ethno maps, with focus on territorial aspects dialogued through PRD. This dialogical methodology of ethno maps construction, proved to be efficient to stimulated the participation of the community and to propitiated the manifestation of the individuals. As well as in the Aruanda community, experience in Itanhém (Chaves and Colli, 2006), the tool map of community allowed to discuss occupation manners of the landscape based on territory and culture, and, in our case revealed important spaces, as community system of fields, places of fruitful (as the jabuticaba trees), school, lake, field, forest, besides the homes.

Finally, we could discuss the reality we try to report in the ethno maps, once that the maps look, in the first view, as a whole translation of physical spatiality, been constituted by limits as data without a discussion possibility. However we know that, 
even under the natural appearance of limits, they are natural references (geographic forms), don't let pass as a socio historical translation.

We could also affirm that the reality here is the expression and the translation of who live in the studied territory, study that developed by collective methodologies that aimed to break, or even attenuate, the vertical relation that characterize the science in its dichotomy, between the research object and the subject. We worked to elaborate a study in which the construction/translation of 'reality' was not only produced by the researchers (dominant perspective), but like a conjunction of perspectives, represented by the researchers together with the people that participated as subject of their own process.

Our simple experience to produce science in a participative way, in our point of view, try to dialog with the Bruno Latour (2001) observations, principally breaking the knowledge perception funded into the dualism represented in the expressions: subject/object and watcher/watched. This duality should be thought as necessary to the science rationality, because should be as corollary for the whole translation of one reality. Contrarily, our work tried to break this duality, but even doing so, could we get the whole reality translation, or the closest from what we could call of truth?

Bruno Latour (2001) comments about the use of maps in scientific researches, and how the scientist dominate the world; however this same world has to be translated into concepts and forms: yes, the scientists dominate the world - but since the world came until them in the form of bidirectional inscriptions, super posts and combined. If this happens with the science production, we perceive that the same happen with the ethno maps, since the references that constitute the drawn and the map are social representations that the Pataxó people do of their territory, there are codes, concepts and inscriptions that mean the living world and its spatiality.

However we find out that the ethno map Pataxó produced (even elaborated from the Pataxó point of view), was favored by the knowledge and instruments elaborated from other disciplines areas represented on the use do GPS and GIS. So, the georeferenced positions are well accepted because the precision that the equipments are known to have, but even in face of this aspect of precision available in the market, they don't spoken about the world, but build representations that sometime are pushed far way, other time approached. In the same way occur with the Pataxó's representation about their territory, when they draw their community, 
their representation, theydon't talk about the own world, but about the world as a stage of a theater where those representation are realized.

\section{CONCLUSIONS}

In this sense, we also observed the difference of the maps made without the participation of its actors, which consists in a representation of certain space determined by the community as important and not the whole space or the space determined for someone else. The confection of the ethno maps and the discussion of them generated reflections regarding the local reality. Were thought situations from current time, that deviate of the old scenario, as change in the cultivation system, the growth number of the families, and the amount and water quality.

The reflections about the space, in turn, facilitated the perception of vulnerability factors and of measures that are, or are not being taken to regarding them. In that sense, was possible to meditate as expected, the cultural, social, political and environmental aspects for the social technology construction.

In this context the digital technology is indispensable and the resources, limited. Still, the used resources were understood by the community that participated in the whole process. However, although it is still restricted the access to instruments (GPS) and to computer programs for mapping, the activity is viable for indigenous communities. The indigenous, like most Brazilians, have easiness using cell phones or devices like music and video players, that don't differ a lot in commands and handling, such like a standard GPS.

We noticed that is possible to promote the exercise of political power by local traditional people, to lead their cultural diversity and biodiversity conservation. It is important to point out that the community development in this process can be stimulated by the construction of autonomy and empowerment of those traditional people.

\section{Acknowledgements}

To the all Imbiruçu indigenous for the support in this study. Especially to the Cacique Romildo Pataxó and the Pataxó students Keyla Francis de Jesus da Conceição and Wakey Silva dos Santos (Junior Scientific Initiation Scholarship, UFVJM). To the Fundação de Amparo a Pesquisa do Estado de Minas Gerais (Fapemig) and to the National Council for Scientific and Technological Development (CNPq), for the scholarships. 


\section{REFERENCES}

ANGTHICHAY, ARARIBY, JASSANÃ, MANGUAHÃ, \& KANÁTYO. O povo Pataxó e suas histórias. 6.ed. São Paulo: Global, 47p., 2002.

BLACK, J. Mapas e história: construindo imagens do passado. 1.ed. Bauru, SP: EDUSC, 428p., 2005.

CAMPOS, R.C. Movimentos indígenas por educação: novos sujeitos socioculturais na história recente do Brasil. In: Reunião Anual da ANPED, n.23, Caxambu, 2000.

CARVALHO, A. $\mathbf{O}$ geoprocessamento na gestão ambiental em Terras Indígenas: uma experiência com etnomapeamento junto à Comissão Pró-Índio do Acre. Science Master Dissertation (Physical Geography). Geography Department, Faculdade de Filosofia, Letras e Ciências Humanas, USP, São Paulo, 127p., 2006.

CEDEFES. Centro de Documentação Eloy Ferreira da Silva. A luta dos índios pela terra: Contribuição a história indígena de Minas Gerais. 1.ed. Contagem, 120p., 1987.

CEDEFES. Centro de Documentação Eloy Ferreira da Silva. (2006). Pataxó: Quem é esse povo? Disponível em: $<$ http://www.cedefes.org.br/new/index.php?conteudo=materias/index\&secao=1\&tema $=53 \&$ materia $=1774>$ Acesso em: 15/06/2010.

CHAMBERS, R. The origins and practice of participatory rural appraisal. World Development, v. 22, n. 7, p. 953-969, 1994.

CHAVES, A. S.; COLLI, F. Processos educativos Revista Terra Viva: estratégias, ações, resultados e desafios na disseminação agroflorestal. Brasília: Ministério do Meio Ambiente. Série Sistematização v. 1, p. 22-33, 2006.

CORREIA, C. S. Etnozoneamento, etnomapeamento e diagnóstico etno ambiental: representações cartográficas e gestão territorial em Terras Indígenas no Estado do Acre. PhD Thesis (Antropology) - Antropology Department, UnB, Brasília, 420p., 2007.

FARIA, A. A. C. O uso do diagnóstico rural participativo em processos de desenvolvimento local: um estudo de caso. Dissertation (Master Science) Universidade Federal de Viçosa, UFV, Viçosa, 111p., 2000.

FREIRE, P. Pedagogia da autonomia - Saberes necessários à prática educativa. São Paulo: Paz e Terra, 37 ed., 148p., 1996.

HARLEY, J. B. Maps, knowledge, and power. In: Cosgrove, Denis \& Daniels, Stephen (org.). The iconography of landscape: Essays on the symbolic representation, design and use of post environments. Cambridge University Press, 1 ed., 162p, 1988. 
HERLIHY, P. H.; KNAPP, G. Maps of, by, and for the peoples of Latin America. In: Human organization. Journal of the Society for Applied Anthropology, v. 62, n. 4, p. 303-314, 2003.

IBGE. Instituto Brasileiro de Geografia e Estatística. (2007). <http://www.ibge.gov.br> LATOUR, B. A esperança de Pandorra: Ensaios sobre a realidade dos estudos científicos. Bauru, SP : EDUSC, 2001, 372p.

LAURIOLA, V. Ecologia global contra diversidade cultural? Conservação da natureza e povos indígenas no Brasil. O Monte Roraima entre Parque Nacional e a Terra Indígena Raposa-Serra do Sol. Revista Ambiente \& Sociedade, v. 5, n. 2, p. 165189, 2003.

LITTLE, P. Gestão territorial em Terras Indígenas: definição de conceitos e proposta de diretrizes. Secretaria de Estado de Meio Ambiente e Recursos Naturais - SEMA-AC, Secretaria Extraordinária dos Povos Indígenas - SEPI-AC e Agência de Cooperação Técnica Alemã (GTZ) no Brasil - GTZ, Rio Branco, Acre, 2006.

MELO, W. F., SILVA, S. S., TAVARES, R. A., FRESCHI, J. M., GAVAZZI, R. A., SILVA, J. F. M., PIYANKO, B., APIWTXA, C. A., BROWN, I. F. Aplicação de dados SRTM, sensoriamento remoto e SIG em etnomapeamento: o caso da Terra Indígena Kampa do Rio Amônia na fronteira Brasil-Acre/Peru-Ucayali. In: Simpósio Brasileiro de Sensoriamento Remoto, INPE, n.13, Florianópolis, SC, 2007. Disponível em: <http://marte.dpi.inpe.br/col/dpi.inpe.br/sbsr@80/2006/11.15.23.05/doc/59495956.pdf $>$ Acesso em 15/06/2010

ORLOVE, B. Mapping reeds and reading maps: the politics of representation in Lake Titicac. American Ethnologist, v. 18, n. 1, p. 3ᄀ38, 1991.

PATAXÓ, R. Encontro com o povo Pataxó de Carmesia. Grupo de Estudos dos Povos Indígenas de Minas Gerais. Universidade Federal dos Vales do Jequitinhonha e Mucuri (UFVJM). Campus I Diamantina, Brazil, 2008.

SCHWARTZMAN, S., ZIMMERMAN, B. Conservation alliances with indigenous peoples of the Amazon. Conservation Biology, v. 19, n. 3, p. 721-727, 2005.

SMITH, D. A. Participatory mapping of community lands and hunting yields among the bugle of Western Panama. Human Organization. Journal of the Society for Applied Anthropology, v. 62, n. 4, p. 332-343, 2003.

THE NATURE CONSERVATION. Etnomapeamento nas comunidades indígenas

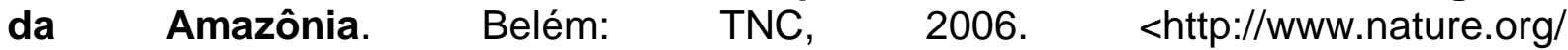
wherewework/southamerica/brasil/work/art16607.html>

VERDEJO M. E. Diagnóstico Rural Participativo. Guia Prático. 1.ed. Brasília: Ministério do Desenvolvimento Agrário, 62 p., 2006. 
VIRGILIO H, BARROS M. V. Z SIG aplicado à caracterização sócio ambiental da reserva indígena Apucarana (PR). Estudos Geográficos, v. 5, n. 1, p. 47-62, 2007. Disponível em: <http://cecemca.rc.unesp.br/ojs/index.php/estgeo>. Acesso em 15/06/2010. 